\title{
Рискови фактори за развитието на отитис медиа катаралис
}

\author{
Сп. Тодоров дм, \\ Клиника по УНГ-болести при УМБАЛ „Ц. Йоанна-ИСУЛ“ЕАД - София
}

\begin{abstract}
Резюме
Авторьт разглежда най-честите рискови фактори за появата и развитието на рецидивиращ остър отит. От страна на микроорганизма това е нарастващата резистентност на най-честите причинители на острия отит, свързана с широката и често неправилна употреба на антибиотиците. От страна на макроорганизма влияние оказва следните фактори: малка възраст на детето ( до 2 години), изкуственото хранене, отглеждането в детски ясли и градини, пасивното тютюнопушене, аденоидната вегетация, алергията и ниския социално-икономически статус на родителите. Важен фактор е и правилното приложение на антибиотиците при лечението на първия пристьп от остър отит. За избягване на рецидивите е необходимо антибиотикът да се прилага в максимална доза и достатъчно продължително време.
\end{abstract}

\begin{abstract}
The author is reviewing the most common risk factors for the appearance and development of the acute recurring otitis. From the side of the microorganism, this is the increasing resistance of the most common causes for the acute otitis, connected with the wide and often improper use of antibiotics. From the part of the macro organism, the following factors have a big influence: the young age of the child (up to two years old), bottle-feeding, the stay in kinder gardens, passive smoking, vegetatio adenoidea, allergies and the low social status of the parents. An important factor is the proper use of antibiotics during the treatment of the first outburst of acute otitis. In order to prevent the recurrences, it is necessary the antibiotic to be given in maximal doses and for a long enough period of time.
\end{abstract}

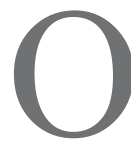
строто възпаление на средното ухо се среща във всички възрасти, но от него боледуват предимно децата. Независимо от постиженията на съвременната медицина честотата на това заболяване непрекъснато нараства (1). Клиничният опит показва, че по отношение на острия отит болните могат да се разделят на три групи: 1. Болни, които никога не са страдали от отит. 2. Болни, които са боледували един или два пъти през детството и 3. Деца, които боледуват много често от отити (2).

Рецидивиращ остьр отит имаме тогава, когато в течение на 6 месеца детето заболее три или повече пъти от отит или когато е имало най-малко 4 пристъпа през последните 12 месеца. В междупристъпния период липсват всякакви данни за заболяване на средното ухо.

През 1975 год. Howie et al. (3) първи предложиха концепцията за „деца склонни към отит“ (otitisprone children ). Според тях, ако едно дете заболее от остър отит до навършване на една-годишна възраст, вероятността от по-късни рецидиви при него е много голяма. В последствие бяха установени и други рискови фактори за появата на резидивиращия отит. Според нас тези фактори могат да се разделят на три групи:

a) Такива, свързани с патогенния микроорганизъм

б) Фактори, свързани с макроорганизма

в) Фактори, свързани с антибиотичното лечение. 


\section{Фактори свързани с патогенния микроорганизъм}

Причинителите на рецидивиращия отит са същите както и при острия среден отит - Streptococcus pneumoniae, Haemophyllus influenzae, Streptococcus pyogenes, Moraxella catarrhalis и по-рядко Staph. aureus. През последното десетилетие всички гореизброени микроорганизми показват все по-голяма резистентност към антибиотиците от първи ред ( пеницилин, еритран, амоксицилин), което налага използването на все по-мощни и скъпо струващи антибиотици. За съжаление и при последните се наблюдават неудачи. Т. напр. неудачите при Str. pneumoniae ca свързани с приложението на Ceftibuten (Cedax) и Cefixime (Pancef), а на Н. Influenzae - c Cefprozil (Cefzil). И двата микроорганизма често са резистентни към Azithromycin, Clarithromycin u Cefaclor (4).

Резистентността не винаги е причина за неуспеха от лечението на острия среден отит и за появата на резидивиращ отит. Клиничният опит показва, че при комбинирана инфекция на средното ухо с вируси и бактерии, процентьт на клиничния неуспех е много висок, въпреки че сам по себе си бактериалният причинител е чувствителен на дадения антибиотик. Според някои автори (5) това се дължи на факта, че вирусите намаляват пенетрационната способност на антибиотиците в средното ухо.

В други случаи рецидивите на острия отит могат да се причинят от друг вид патогенен микроорганизъм. Carlin et al. (6) установяват, че в $75 \%$ от случаите с рецидивиращ отит отделните епизоди се причиняват от различни по вид патогени.

В около $30 \%$ от децата с рецидивиращ отит изследването на ексудата от средното ухо показва липса на бактериален растеж. Тези „стерилни“ култури могат да се дължат на чисто вирусна инфекция, на проведеното предварително антибиотично лечение, на ролята на локалния и общ имунен отговор или на несъвършенствата на класическите методи за микробиологично изследване. Ehrlich (7) е изследвал 97 аспирата от средното ухо и е установил, че $28,9 \%$ от тях дават положителен растеж при класическото микробиологично изследване, докато при използване на PCR (polimerase chain reaction) този процент е 77\%. Бактерият може да загуби способността си за размножение, но да остане метаболитно активен. Така може да се обясни появата на рецидив на отита при първата респираторна инфекция.

\section{Фактори свързани с макроорганизма}

1. Пол. Според чужди и наши проучвания децата от мъжки пол боледуват около два пъти по-често от рецидивиращ отит отколкото децата от женски пол.

2. Възраст. Най-голяма заболяемост (около $30 \%$ ) от рецидивиращ отит показват децата до 2-годишна възраст (8).

3. Начин на хранене. Доказано е, че изкуствено хранените кърмачета боледуват от рецидивиращ отит около пет пъти повече, отколкото тези, които са кърмени поне първите три месеца след раждането (9). Освен това храненето с биберон в легнало положение сьщо увеличава риска от поява на отит.

4. Начин на отглеждане. Децата, които посещават детски ясли и градини боледуват $6-7$ пъти по-често от отити в сравнение с децата отглеждани в домашна обстановка (10). При ясленските деца се установява и по-висок процент на резистентни щамове (11).

5. Пасивно тютюнопушене. Като използват биохимичен маркер за установяване на отлагането на никотин в организма, Etzel et al. (12) първи доказаха, че пасивното тютюнопушене в семейството увеличава 8 - 10 пъти вероятността от поява на рецидивиращ отит.

6. Аденоидната вегетация също играе роля при поява на рецидивиращия отит. Най-често тя е източник на инфекция, която не се влияе от рутинното антибиотичнто лечение. Тази инфекция периодично преминава през Евстахиевата тръба и реинфектира средното ухо. Много по-рядко се касае за хипертрофия на вегетацията, която с големината си възпрепятствува нормалната вентилация на средното ухо и улеснява появата на отит.

7. Ролята на алергията е все още дискутабилен проблем, но при $30-40 \%$ от децата с рецидивиращ отит се установява различен тип алергия (13). Ние установихме данни за алергия при $28 \%$ от децата с рецидивиращ отит.

8. Имунодефицит. Много изследвания сочат, че деца с рецидивиращ отит са с по-ниски нива на IgG2 и секреторен IgA в сравнение със здрави деца (14). 
9. Ниският социално-икономически статус на някои групи от населението също играе роля за появата на рецидивиращ отит.

\section{Роля на антибиотиците в генезата на рецидивиращия отит}

Освен чрез създаване на резистентност, антибиотиците могат да провокират появата на рецидивиращ отит и по друг начин. Става дума за неправилно антибиотично лечение на острия пристьп на средния отит.

От една страна, когато антибиотикът се приложи още в началото на отита, той ще доведе до бързо елиминиране на патогена от средното ухо и по-слабо антигенно дразнене. Поради ниския титьр на така формираните антитела, същата инфекция може да предизвика ново заболяване, т.е. рецидив. По тази причина много водещи отолози са единодушни, че задължителното лечение на всеки остьр отит с антибиотици е осъдително (15).

От друга страна, неправилното приложение на антибиотиците при лечението на острия отит, също може да създаде условия за рецидив. Тук трябва да се съобразяваме с обстоятелството, че възпалението протича в една затворена кухина, което удължава оздравителния период и създава условия за протрахиране и рецидиви. Ето защо най-добрата профилактика на рецидивиращия отит е ефикасното лечение на острия отит, което се постига чрез:

\section{Литература}

1. Schappert SM. - Office visits for otitis media in USA 1975 - 1990. From Vital and Healt Statistics of the Centers for Disease Control. 1992; 214: 1-18.

2. Klein JO. - Prevention of Severe and Recurrent Otitis Media. OtoRhino-Laryngol. Nova,1998; 8: 154-159.

3. Howie W., Ploussard J., Sloyer J. - The „otitis-prone“ children condition. Ann. J. Dis. Child. 1975; 129: 676-698.

4. McCracken GH. - Treatment of acute otitis media in an era of increasing microbial resistans. Pedatr. Infect. Dis. J., 1998; 17: 576 -579 .

5. Canafax D. - Factors affecting middle ear antibiotic penetration. Inf. Clin. Pact. Series. 1996; 15-20.

6. Carlin SA., Marchant CD., Shurin PA., Johnson CE., MurdellPanek D., Barenkamp SJ. - Early recurrence of otitis media: reinfection or relapse? J. Pediatr. 1987; 110: 20-25.

7. Ehrlich G. - What do new diagnostics tell us about the effectivenes of treatment of otitis media. Int. Clin. Pract. Series. 1996; 913.

8. Pichichero ME. - Acute Otitis Media; Part II: Treatment in an Era of Increasing Antibiotic Resistans. Am. Fam. Physician. 2000; 61: 2051-2056. a) Избор на най-подходящ антибиотик. При пациенти, които не са лекувани през последните два месеца с антибиотик, най-подходящото средство за лечение на острия отит е амоксицилинът. Ако обаче през това време е прилагано антибиотично лечение, по-уместно е да се приложи някой бета-лактамазорезистентен антибиотик (Augmentin, Zinnat).

б) Постигане на оптимална тьканна концентрация на антибиотика. Това се постига чрез приложение на максималната единична доза на съответния антибиотик.

в) Оптимална продължителност на лечението. Натрупаният клиничен опит е показал, че срокът на лечение на острия отит е минимум $8-10$ дни.

\section{Заключение}

Познаването на рисковите фактори за поява на рецидивиращия отит е предпоставка както за адекватното лечение на това заболяване, така и за неговата профилактика.

В много случаи правилно избраният антибиотик, приложен в максимална доза и продължителност, води до пълно оздравяване.

При неуспех от такова лечение може да се пристьпи към оперативна интервенция - аденоидектомия и/или тимпаностомия.
9. Paradise JL., Elster BA. - Breast milk protects against otitis media. J. Pediatr. Res. 1984; 18: 283.

10. Wald ER., Dachefsky B., Byers C. et al. - Frequency and sevsrity of infections in day care. J. Pediatr. Res. 1988; 112: 540-546.

11. Reichler MR., Allphin AA., Breiman RF. - The spread of multiply resistant Streptococcus pneumoniae at a day care center in Ohio. J. Inf. Dis. 1992; 166: 1346-1353.

12. Etzel RA., Rattishall EN., Halley NJ. - Passive smoking and middle ear effusion among children in day care. Pediatrics. 1992; 90: $228-232$

13. Fior R., Pechiulli G., Samani F., Pastorinr S. - Rezidivierende Otitis media in Kindesalter. HNO-Praxis. 1990; 4: 295-299.

14. Kobayashi K., Kataura A. - The role of secretory IgA and surfactant in the pathogenesis of recurrent otitis media. II Extraordinary International Symposium on Recent Advances in Otitis Media / Res/, Oita, 1993; 125A.

15. Pichichero M. - Evaluation of alternative treatmens inacute otitis media. Pediatr. Inf. Dis. J. 1994; 13: 1, 28-33. 